\title{
Sentimental Masculinity: HENRY MACKENZIE'S THE MAN OF FEELING (1771)
}

\author{
RAINER EMIG
}

\begin{abstract}
Sentimental fiction is nowadays often seen as the province of a femininity slowly asserting itself against all patriarchal odds. Pamela and Clarissa have become the heroines in this one-sided story. However, sentimental fiction and the philosophy that goes hand in hand with it also had important effects on the reformulation of acceptable modes of masculinity. Harley, the protagonist of Mackenzie's seminal short novel, is such a transitional figure who is torn between privilege and individual virtue, rationality and feeling, expected strength and appropriate weakness. In him we can see a trial run of modern masculinity - or rather of the various acceptable shapes of modern masculinities. He also offers a suitable illustration of the transition from Neoclassical to Romantic to bourgeois masculinity. The fact that he does not survive his own story but is torn apart by his contradictions points towards impasses in masculine roles with which we are still struggling today.
\end{abstract}

The term "sentimental" and the concept of sentimentality are nowadays firmly associated with femininity. An emphasis on emotions and their entanglement with the body and its affects fits into modern stereotypes of the weaker sex. Victor J. Seidler's painfully sweeping study Transforming Masculinities reproduces this cliché: "emotions are interpreted as 'feminine' and so as a threat to male identities, and partly because masculinities are identified with self-control as a mode of dominance in which reason supposedly silences inner emotions, feel- 
ings and desires." "Yet when Sentimentalism emerged as a philosophical and aesthetic tendency in the eighteenth century, it was originally a universal concept. In fact, when one studies the ideas of the foremost British exponent of sentimental philosophy, Anthony Ashley Cooper, Earl of Shaftesbury (1671-1713), one cannot say whether his descriptions refer to male or female observers or if they describe masculine or feminine qualities. In this vein, he states that the moral sense of the mind

... feels the soft and harsh, the agreeable and disagreeable in the affections, and finds a foul and fair, a harmonious and a dissonant, as really and truly here, as in any musical numbers or in the outward forms or representations of sensible things. Nor can it withhold its admiration and ecstasy, its aversion and scorn, any more in what relates to one than to the other of these subjects. ${ }^{2}$

In another, later passage, he goes even further:

No sooner the eye opens upon figures, the ear to sounds, than straight the beautiful results and grace and harmony are known and acknowledged. No sooner are actions viewed, no sooner the human affections and passions discerned (and they are most of them as soon discerned as felt) than straight an inward eye distinguishes and sees the fair and shapely, the amiable and admirable, apart from the deformed, the foul, the odious or the despicable. ${ }^{3}$

Chester Chapin indeed sees Cooper's life and career as a mirror of that of many failed sentimental heroes. ${ }^{4}$ Janet Todd's seminal study of Sensibility also upholds the non-gendered status of sentimental writing. In its introduction she writes:

The sentimental work reveals a belief in the appealing and aesthetic quality of virtue, displayed in a naughty world through a vague and

\footnotetext{
${ }^{1}$ Victor J. Seidler, Transforming Masculinities: Men, Cultures, Bodies, Power, Sex and Love, London: Routledge, 2006, 25.

${ }^{2}$ Anthony Ashley Cooper, Characteristics of Men, Manners, Opinions, Times, ed. Lawrence E. Klein, Cambridge Texts in the History of Philosophy, Cambridge: Cambridge University Press, 1999, 172-73.

${ }^{3}$ Ibid., 326.

${ }^{4}$ See Chester Chapin, "Shaftesbury and the Man of Feeling", Modern Philology, LXXXI/1 (August 1983), 47-50.
} 
potent distress. This distress is rarely deserved and is somehow in the nature of things; in later sentimental works it even overshadows virtue, which may in fact be more manifest in the sympathy of the observer than in the sufferer. The distressed are natural victims, whose misery is demanded by their predicament as defenseless women, aged men, helpless infants or melancholic youths. ${ }^{5}$

The idea that emotions were not only linked to moral ideas of virtue but also explicable in rational terms shows that Sentimentalism is not a simple opposition to Enlightenment rationality. Another important philosophical influence in the context of Sentimentalism, David Hume, had already declared in his Treatise of Human Nature (17391740): "A propensity to the tender passions makes a man agreeable and useful in all the parts of life; and gives a just direction to all his other qualities, which otherwise may become prejudicial to society." Sentimentalism therefore indeed paved the way for the transition of rationalist Neoclassicism to the ideologies and aesthetics of Romanticism. The merger of Romanticism and bourgeois pragmatism, one could argue, in turn prepared the path for the modern thinking to which, in terms of gender and sexuality, we still adhere. This makes it all the more necessary to understand Sentimentalism in terms of gender.

The literary manifestations of Sentimentalism were also to a considerable degree male: Sarah Fielding's The Adventures of David Simple (1744), Henry Brooke's, The Fool of Quality (1766-1772), Oliver Goldsmith's The Vicar of Wakefield (1766), Laurence Sterne's A Sentimental Journey (1768) and Henry Mackenzie's The Man of Feeling all feature men as their protagonists. ${ }^{7}$ That these are unusual heroes becomes evident in the strong ambivalence that many of them exerted even in their own time and all the more so today: are they comic fig-

\footnotetext{
${ }^{5}$ Janet Todd, Sensibility: An Introduction, London: Methuen, 1986, 2-3.

${ }^{6}$ David Hume, A Treatise of Human Nature, ed. P.H. Nidditch, 2nd edn, Oxford: Clarendon Press, 1978, 603-604.

${ }^{7}$ Patricia Meyer Spacks believes this to be the result of the eclipsing of female authored texts by male authored ones. Yet even she has to admit, in a critical aside on Janet Todd, that an easy gendering of sensibility as feminine is problematic: "Janet Todd observes that the 'cult of sensibility stressed those qualities considered feminine in the sexual psychology of the time,' specifying 'intuitive sympathy, susceptibility, emotionalism and passivity.' But the attribution of sensibility to women did not seem so bland a matter to eighteenth-century female writers" (Meyer Spacks, quoted in Todd, Sensibility, 110).
} 
ures, or are we supposed to take them seriously? Only Sterne's Parson Yorick is clearly marked as a comic hero. At the time of the novels' first publication, Goldsmith's tragic vicar and Mackenzie's equally doomed hero in particular were taken very seriously. In a letter by Lady Louisa Stuart from 1826 she describes her surprise at the reaction of a group of country-house readers to the novel she, her mother and sisters had been weeping over when it first appeared: "Nobody cried, and at some passages, the touches that I used to think so exquisite - oh dear! They laughed."

The present essay will try to link the multiple borderlines on which sentimental fiction is located: serious versus comical, Enlightenment rationalism versus proto-Romantic emotionality, and masculinity versus its supposed binary opposite, femininity. It will attempt to prove that sentimental heroes, such as Mackenzie's Harley, represent trial runs of a new masculinity, one whose legacy is still with us when we debate for instance "new men". At the same time, such eighteenthcentury attempts to redefine the dominant gender of patriarchy will be employed to show that masculinity - already in its early "conceptual" manifestations - was a far cry from essentialist, and therefore probably superior to some contemporary backlashes that try to tie masculinity to the body and psyche in naïve and simplistic fashions.

The "Man of Feeling", a country gentleman called "Harley", is clearly not the norm when the reader encounters him posthumously for the first time in Mackenzie's novel. His very first introduction by a narrator already calls him "whimsical", an adjective that implies a simultaneous lack of relevance and predictability, two qualities that a man of his rank ought to possess. In fact, Harley is in many ways a failure. He lacks integrity, a fact that is already aptly demonstrated by the medium in which he has managed to manifest himself. What he has left behind are incoherent notes that do not amount to a history or a sermon. Neither do they represent philosophical aphorisms, another acceptable genre for a male writer. These notes are further fragmented by their present owner, who uses them to clean his hunting gun:

"Some time ago," said he, "one Harley lived there, a whimsical sort of man I am told, but I was not then in the cure; though, if I had a turn

\footnotetext{
${ }^{8}$ Stephen Bending and Stephen Bygrave, Introduction, The Man of Feeling, ed. Brian Vickers, Oxford World's Classics, Oxford: Oxford University Press, 2001, xv. All quotations from Henry Mackenzie's The Man of Feeling are from this edition.
} 
for those things, I might know a good deal of his history, for the greatest part of it is still in my possession."

"His history!" said I. "Nay, you may call it what you please," said the curate; "for indeed it is no more a history than it is a sermon." ....

"Soon after I was made curate, he left the parish, and went no body knows whither; and in his room was found a bundle of papers, which was brought to me by his landlord. I began to read them, but I soon grew weary of the task; for, besides that the hand is intolerably bad, I could never find the author in one strain for two chapters together; and I don't believe there's a single syllogism from beginning to end."

Harley does not fit into masculine patterns of self-representation through his loose ends and unacceptable openness. ${ }^{10}$ This also affects his behavior, for he cannot control himself and lets his feelings run away with him. Here is a description of how he behaves in the company of a maiden aunt who might leave him a fortune:

... notwithstanding the instructions he daily received, his visits rather tended to alienate than gain the good-will of his kinswoman. He sometimes looked grave when the old lady told the jokes of her youth; he often refused to eat when she pressed him, and was seldom or never provided with sugar-candy or liquorice when she was seized with a fit of coughing: nay, he had once the rudeness to fall asleep, while she was describing the composition and virtues of her favourite cholicwater. In short, he accommodated himself so ill to her humour, that she died, and did not leave him a farthing. ${ }^{11}$

Within the framework of eighteenth-century politeness, his behavior is unacceptable. Within the framework of eighteenth-century Sentimentalism, however, his conduct is honest and therefore virtuous. Virtuousness clashing with the demands of his gender and class is a shorthand description of Harley's problem. This goes as far as making him incapable of proposing marriage to a wealthy heiress who not only lives nearby, but clearly likes him. Believing himself to be beneath her in terms of wealth, but more importantly feeling far too much for her

\footnotetext{
${ }^{9}$ Mackenzie, The Man of Feeling, 4.

${ }^{10}$ See Rainer Emig, "Madness, Eccentricity, Sociability: Henry Mackenzie's The Man of Feeling (1771) and the Trials of Modernising the British Subject", in Einsamkeit und Geselligkeit um 1800, ed. Susanne Schmid, Regensburger Beiträge zur Gender Forschung 3, Heidelberg: Winter, 2008, 163-75.

${ }^{11}$ Mackenzie, The Man of Feeling, 11.
} 
to be able to put this into the mercenary terms of a marriage contract, he dies after declaring his love for her.

Why is Harley so different from the norms of his class in terms of his gendered attitudes? The text rather weakly tries to explain this through the early loss of his father and his insufficient replacement as a role model by a group of guardians:

He lost his father, the last surviving of his parents, as I have already related, when he was a boy. The good man, from a fear of offending, as well as a regard to his son, had named him a variety of guardians; one consequence of which was, that they seldom met at all to consider the affairs of their ward; and when they did meet, their opinions were so opposite, that the only possible method of conciliation, was the mediatory power of a dinner and a bottle, which commonly interrupted, not ended, the dispute; and after that interruption ceased, left the consulting parties in a condition not very proper for adjusting it. ${ }^{12}$

Yet this is a fairly common situation for a man of his time. Patriarchy never needed to manifest itself in the direct transmission of knowledge and power from father to son. It could always rely on substitutes, such as institutions or abstract ideologies, to perform its task. Yet in The Man of Feeling neither of these seems to work. Harley refuses to accept his inherited role of country gentleman. He shows himself remarkably immune and even reluctant concerning the worldly things that were considered appropriate for a man of his standing.

The long introduction to the important Chapter XII of the novel makes this abundantly clear:

\section{CHAPTER XII - OF WORLDLY INTERESTS}

There are certain interests which the world supposes every man to have, and which therefore are properly enough termed worldly; but the world is apt to make an erroneous estimate: ignorant of the dispositions which constitute our happiness or misery, they bring to an undistinguished scale the means of the one, as connected with power, wealth, or grandeur, and of the other with their contraries. Philosophers and poets have often protested against this decision; but their arguments have been despised as declamatory, or ridiculed as romantic.

${ }^{12}$ Ibid., 10. 
There are never wanting to a young man some grave and prudent friends to set him right in this particular, if he need it; to watch his ideas as they arise, and point them to those objects which a wise man should never forget. Harley did not want for some monitors of this sort. He was frequently told of men whose fortunes enabled them to command all the luxuries of life, whose fortunes were of their own acquirement: his envy was invited by a description of their happiness, and his emulation by a recital of the means which had procured it.

Harley was apt to hear those lectures with indifference; nay, sometimes they got the better of his temper .... ${ }^{13}$

Mackenzie's text clearly positions Harley on the romantic rather than the materialist side. More than that, it shows him rejecting the homosocial influence that made men in the eighteenth century as much as it makes them nowadays. In practical terms, this means that he foregoes the chance of gaining the title to a significant property. In fact, he allows himself to be tricked out of it. The text had, in fact, hinted at such an outcome when introducing the sub-plot concerning crownland with the mention of "interest with the great, which Harley or his father never possessed". ${ }^{14}$

Harley's "interests" are not possessions. Harley defines his happiness through himself, through his passions, his feelings, as the title of the novel emphasizes. ${ }^{15}$ Their litmus test lies in the affects that literally affect his body. The body was meant to be the medium on which true sentiments expressed themselves: as blushing and turning pale, as smiling and yawning, in extreme cases as tears or even fainting fits. Once again, we see things through a modern or at least Victorian lens when we identify these bodily symptoms with femininity. Indeed Harley is the prime example of the violation of the modern rule "boys don't cry", for he indeed cries forty-nine times in the roughly hundred-and-fifty pages of the slim novel. Later editors even indexed his tears, so central did they appear to an understanding of the protagonist. $^{16}$

${ }^{13}$ Ibid., 9-10.

${ }^{14}$ Ibid., 11.

${ }^{15}$ In an often problematic attempt to describe Harley as the focus of the novel's sexualization of reality, George E. Haggerty also concludes that "His desire is merely selfdirected after all" (George E. Haggerty, Men in Love: Masculinity and Sexuality in the Eighteenth Century, Between Men - Between Women: Lesbian and Gay Studies, New York: Columbia University Press, 1999, 90).

${ }^{16}$ See Mackenzie, The Man of Feeling, 110-11. 
Bodily integrity, masculinity studies generally agree, is a major test of masculinity, and its only legitimate violation is bloodshed in situations of attack or defense. It is all the more fascinating that, despite this link between weeping and non-masculine behavior, Mackenzie's text at no time calls Harley's attitude "effeminate". Indeed, it makes clear that Harley not only cries frequently, but that he also believes honest tears to be a thing of beauty. He is not merely sentimental, he is also a believer in Sentimentalism: "A blush, a phrase of affability to an inferior, a tear at a moving tale, were to him, like the Cestus of Cytherea, unequalled in conferring beauty." ${ }^{17}$ A "cestus", interestingly enough, is both a woman's belt or girdle, fastened beneath the breast, and a leather strap for the hand of a boxer in ancient Greece and Rome. The support that affects provide can be feminine or masculine.

The same is true for tears. Tears have a moral value in Sentimentalism and thus also for Harley, as becomes clear when the narrative comments on his reaction to the sad tale of a love-struck young gentlewoman who is now in Bedlam, the infamous London mental asylum: "he had given it the tribute of some tears." 18 A little later he comments on the tears of a young woman who has had to resort to prostitution by exclaiming: "there is virtue in these tears." ${ }^{19}$ Virtue, as the name implies, originally a masculine quality, shifted to a feminine one in the time of Shakespeare. Indeed the first recorded use of "virtue" for a woman is in Shakespeare's Much Ado About Nothing. ${ }^{20}$ While it had signified integrity, honor, and bravery for men, it increasingly came to mean chastity for women. Virtue in The Man of Feeling, however, is non-gendered and can be applied to men and women alike. It can even be mediated between the sexes through sympathy in its original sense: joint suffering. In a manner already prefiguring Wordsworth's emotion recollected in tranquility, Harley cries again when he remembers the tears he and the young woman have shed during their encounter:

He rose, uncertain of his purpose; but the torpor of such considerations was seldom prevalent over the warmth of his nature. He walked

\footnotetext{
${ }^{17}$ Ibid., 12.

${ }^{18}$ Ibid., 26.

${ }^{19}$ Ibid., 38.

${ }^{20}$ See Rainer Emig, "Terror und Verstummen: Gewalt und Widerstand in Shakespeares Komödien", in Shakespeare Jahrbuch 143, eds Ina Schabert et al., Bochum: Kamp, 2007, 92.
} 
some turns backwards and forwards in his room; he recalled the languid form of the fainting wretch to his mind; he wept at the recollection of her tears. ${ }^{21}$

This places the depiction of emotions in The Man of Feeling in an interesting connection with eighteenth-century debates on passion and interest. Susan Kingsley Kent argues that "Transforming passions into interest emptied them of their feminine content .... In transforming the passions - rendered as feminine - into the interests - depicted as masculine - these thinkers [David Hume and Adam Smith] also brought about a transformation of virtue." 22 There is indeed an economy of tears, as becomes evident when Harley hears the sad story of old farmer Edwards who exchanges himself for his press-ganged son and weeps uncontrollably as a result, while the teller of the tale, though directly affected by it, has told it so often that it only provokes a single tear from him: "The old man now paused a moment to take breath. $\mathrm{He}$ eyed Harley's face; it was bathed with tears: the story was grown familiar to himself; he dropped one tear, and no more. ${ }^{, 23}$ At the end of the tale, Harley expends himself once again: "at last he pressed him in his arms, and when he had given vent to the fulness of his heart by a shower of tears, 'Edwards,' said he, 'let me hold thee to my bosom, let me imprint the virtue of thy sufferings on my soul'."

Sympathy and empathy enable not only suffering to be shared and exchanged, but also the transfer of virtue from the victim of circumstances to the sympathetic onlooker. Ideally this also includes the reader. This is where The Man of Feeling doubles up on itself: it depicts its protagonist anxiously consuming passions and transforming them into sympathetic interests - and it encourages its readers to do the same with the help of the novel as a commodity of passion, interest, and virtue. Here it even works backwards, so to speak, by making Edwards lose his reserve: "Edwards, from whom the recollection of his own suffering had scarced forced a tear, now blubbered like a boy." ${ }^{24}$ Markman Ellis, in his study The Politics of Sensibility, describes this in unsentimental terms:

\footnotetext{
${ }^{21}$ Mackenzie, The Man of Feeling, 41.

${ }^{22}$ Susan Kingsley Kent, Gender and Power in Britain, 1640-1990, London: Routledge, 1999, 65.

${ }^{23}$ Mackenzie, The Man of Feeling, 67.

${ }^{24}$ Ibid., 71.
} 
Sensibility was one of the tools of a thorough-going and selfconscious analysis of the emergent consumer-economy of British society and culture. Sensibility was drawn into, and helped define, an increasingly open debate that identified and analysed these problems, and created spaces within public opinion for imagining and creating responses of individual and institutional reform.

The nexus of individual, public and institutional explains the involvement of masculinity. Quoting Paul Langford, Ellis views the cult of sensibility as the expression of "the middle-class need for a code of manners which challenged aristocratic ideals and fashions", in short, as "part of the reformation of the code of genteel contact necessary for the middle class to purchase gentility". ${ }^{25}$

Harley, the upper-class failure who cannot even look after his own interests when it comes to property and income ${ }^{26}$ is indeed very capable of creating interest in others, of affecting them. Here we approach the real reason for Harley's failure in terms of his own class and its increasingly outmoded views of gender: his interests are the wrong ones for them. Yet they are the right ones in terms of a different class who would soon dominate not only the economy of Britain, but also its ideology. Harley's failure as country gentleman endeared him to a bourgeois readership. Their sympathies derive not so much from his anti-materialism - this would indeed disqualify him as a bourgeois tradesman or entrepreneur. What they applauded was his individualism and his idea of virtue that was a far cry from the hollow forms of upper-class honor and politeness. J.G.A. Pocock indeed claims that the new middle-class ideal of the entrepreneur departed from traditional masculine principles embodied by the landed gentry: eighteenth-century economic man, he claims, "was seen as on the whole a feminised, even an effeminate being, still wrestling with his own passions and hysterias and with interior and exterior forces let loose by his fantasies and appetites ... in the eighteenth-century debate over the new relations of polity to economy, production and exchange are

${ }^{25}$ Markman Ellis, The Politics of Sensibility: Race, Gender and Commerce in the Sentimental Novel, Cambridge Studies in Romanticism 18, Cambridge: Cambridge University Press, 1996, 17.

${ }^{26}$ See Maureen Harkin, "Mackenzie's Man of Feeling: Embalming Sensibility”, ELH: English Literary History, LXI/2 (Summer 1994), 324. 
regularly equated with the ascendancy of the passions and the female principle." 27

If Harley consistently refuses to learn from men of his fellow class, he is indeed more influenced by the middle-class ideas of a misanthrope whom he also encounters in Bedlam and who becomes a mouthpiece for the novel's argument against empty formality and in favor of honest sentiment:

"Honour," said he [the misanthrope], "Honour and Politeness! this is the coin of the world, and passes current with the fools of it. You have substituted the shadow Honour, instead of the substance Virtue; and have banished the reality of Friendship for the fictitious semblance which you have termed Politeness: politeness, which consists in a certain ceremonious jargon, more ridiculous to the ear of reason than the voice of a puppet. You have invented sounds, which you worship, though they tyrannize over your peace: and are surrounded with empty forms, which take from the honest emotions of joy, and add to the poignancy of misfortune." - "Sir," said Harley - His friend winked to him, to remind him of the caution he had received. He was silenced by the thought ..... ${ }^{28}$

Harley himself is quite capable of making pronouncements in favor of an anti-aristocratic masculinity that goes hand in hand with an emerging middle-class ethos:

"Perhaps," said Harley, "we now-a-days discourage the romantic turn a little too much. Our boys are prudent too soon. Mistake me not, I do not mean to blame them for want of levity or dissipation; but their pleasures are those of hackneyed vice, blunted to every finer emotion by the repetition of debauch; and their desire of pleasure is warped to the desire of wealth, as the means of procuring it. The immense riches acquired by individuals have erected a standard of ambition, destructive of private morals, and of public virtue. The weaknesses of vice are left us; but the most allowable of our failings we are taught to despise. Love, the passion most natural to the sensibility of youth, has lost the plaintive dignity he once possessed, for the unmeaning simper of a dangling coxcomb; and the only serious concern, that of a dowry,

27 J.G.A. Pocock, "The Mobility of Property and the Rise of Eighteenth-Century Sociology", in Virtue, Commerce, and History: Essays on Political Thought and History, Chiefly in the Eighteenth Century, Cambridge: Cambridge University Press, $1985,114$.

${ }^{28}$ Mackenzie, The Man of Feeling, 30. 
is settled, even amongst the beardless leaders of the dancing-school. The Frivolous and the Interested (might a satirist say) are the characteristical features of the age; they are visible even in the essays of our philosophers. They laugh at the pedantry of our fathers, who complained of the times in which they lived; they are at pains to persuade us how much those were deceived; they pride themselves in defending things as they find them, and in exploding the barren sounds which had been reared into motives for action. To this their style is suited; and the manly tone of reason is exchanged for perpetual efforts at sneer and ridicule. This I hold to be an alarming crisis in the corruption of a state; when not only is virtue declined, and vice prevailing, but when the praises of virtue are forgotten, and the infamy of vice unfelt."

Harley argues against repression, the repression of honest and individual feelings, not of the desires imposed by imitation and peer-pressure. What he has in mind are the homosocial environments of public schools and Oxbridge, which were well known to be degraded into upper-class gathering places without any claim to education, moral or otherwise. What is interesting is that he calls for love as the guiding passion and devalues wealth. It is also noteworthy that he does not see a conflict between his model of positive affection and masculinity or rationality, as his ideal of a "manly tone of reason" 29 demonstrates.

Rather than attacking other countries, Harley's ideal young men defend their ideas of virtue and even explode empty reification. Mackenzie employs the martial rhetoric of masculinity of his time, yet manages to translate it into terms that fit the sentimental ideas of his novel as much as they agree with an emerging middle-class ethos of individual virtue - rather than class-based honor.

That this virtue is here applied to men is important. Men are still considered the sex in charge of society's welfare. Kent indeed reminds us that

... virtue occupies a central place in eighteenth-century English and Scottish political and moral theory. Drawn from the Aristotelian and renaissance republican traditions of citizenship, which saw in participation in civic life the sole means through which men (and it was only men and men of independent wealth) could achieve their full human

${ }^{29}$ Ibid., 61-62. 
potential, virtue signified the capacity of human beings to govern themselves. $^{30}$

Yet the manifestations of this virtue in Mackenzie's novel are remarkably ungendered. There is not a single mention of "masculine", "feminine", or "effeminate" in the text. Not once is Harley compared to a fop - the anti-masculine caricature of earlier decades of the late seventeenth and early eighteenth centuries. "Manly" is indeed employed several times, yet virtue is also possible for women, even the fallen woman whom Harley encounters. The sentimental body, the medium and litmus test of this new concept of a rational as well as emotional virtue, is ungendered. Blushes and tears belong to either sex, and their value is not determined by the body of those who display them, but by the contexts they inhabit. Mackenzie's model of sentimentality is thus a discursive one, and one should not be fooled into believing that an excess of bodily symptoms signals an essentialist attitude of the text.

In fact the text is in many ways wiser than some recent returns to essentializing masculinity. After having abandoned the notion of the male body as determining, for example, aggression and dominance, this essentialism has migrated into the psyche. There, specific psychic dispositions that are themselves mere helpless constructions, such as Asperger Syndrome, are now supposed to be able to explain masculine behavior. ${ }^{32}$ That matters are a good deal more complicated, that we need to see the body as a writing board of historical discourses and gender as one among several of these is what a text like The Man of Feeling upholds. In this respect, too, it still has a lot to teach us.

\footnotetext{
${ }^{30}$ Kent, Gender and Power, 55.

${ }^{31}$ See Michael S. Kimmel, "The Contemporary 'Crisis' of Masculinity in Historical Perspective", in The Making of Masculinities: The New Men's Studies, ed. Harry Brod, London: Allen and Unwin, 1987, 134-35.

${ }^{32}$ See Berthold Schoene, "Serial Masculinity: Psychopathology and Oedipal Violence in Bret Easton Ellis' American Psycho", Modern Fiction Studies, LIV/2 (Summer 2008), 378-97.
} 